\title{
Understory Herbage Production of Major Soils within the Black Hills of South Dakota
}

\author{
D.L. BENNETT, G.D. LEMME, AND P.D. EVENSON
}

\section{Abstract}

Two-year understory production was determined on 6 major forest soils across 2 geomorphic regions in the Black Hills of South Dakota. Stepwise multiple regression was used to determine those variables best explaining yield variability. Canopy cover, basal area, solls, May-June precipitation, and soil $X$ cover interactions further improved the models, which accounted for 65 to $76 \%$ of the variability in herbage production. Footslope, nonskeletal soils had the highest herbage production (vielding $1,800 \mathrm{~kg} / \mathrm{ha}$ at $0 \%$ canopy cover). The least developed, backelope, skeletal soil had the lowest herbage production (producing only $550 \mathrm{~kg} / \mathrm{hn}$ at $0 \%$ canopy cover) from comparable areas of the Black Hills. Developed models can be used in conjunction with soil survey reports to estimate the fornge potential of a given soll mapping unit. Results from this study emphasize the importance of considering the understory vegetation production potential of individual soll series when developing grazable woodland manngement plans. Soil-related production differences were most strongly expressed under conditions of limited overstory canopy cover.

Key Words: forest grazing, understory production, Black Hills, forest soils

The understory of forested lands across the United States is grazed extensively by livestock and wildlife. Heterogeneity in the understory can greatly affect grazing value. As a result, grazing potentials on some forest lands are not well understood.

More than 29,000 cattle grazed nearly 486,000 ha of grazing allotments in the Black Hills National Forest of South Dakota in 1980. An additional 62,000 deer were also living within the same forest boundary. Lack of water, steep topography, and dense timber make all but 194,000 ha of the area unsuitable for grazing (U.S. Forest Service 1983). Thinning dense ponderosa pine (Pinus ponderosa, Douglas) stands would improve forage production on nearly one half of the unsuitable hectarage (U.S. Forest Service 1983).

Numerous models have been developed to link overstory forest structure to understory vegetation production. Inverse linear or curvilinear relationships have been reported in deciduous forests (Ehrenreich and Crosby 1960, Woods et al. 1983), mixed deciduousconiferous forests (Gains et al. 1954, Halls and Schuster 1965, Pyke and Zamore 1982), and coniferous forests (Pase 1958; Clary and Ffolliot 1966; McConnell and Smith 1965, 1970; Wolters 1973, 1982). Canopy cover and basal area have been found to be highly correlated with understory production.

Variables other than overstory structure have also been used to explain yield variability. Wolters (1982) used precipitation in addition to basal area to explain large production differences over a 16-year period in Louisiana. Gains and co-workers (1954) separated upland sites in Alabama by major soil groups. They found that the combined variables of litter weight and soil group explained $31 \%$ of the variability in herbage yield. Ffolliot and Clary (1975) found differences in herbage-timber relationships between paired sites of residual soils derived from limestone and basalt.

McConnell and Smith (1965, 1970) and Pase (1958) reported that vegetation components respond differently to changes in over-

\footnotetext{
Authors are former graduate research assistant, presently with the Soil Conservation Service, Pierre, S.Dak.; associate professors, Plant Science Department, South Dakota State University, Brookings 57007.

This research was supported by McIntire-Stennis funds.

Manuscript accepted 8 September 1986.
}

story structure. In the Black Hills, Pase found grasses more sensitive than forbs or shrubs to increase in canopy cover. The objective of our study was to develop models to predict understory herbage production potential of predominant forest soils in the Black Hills and to investigate the magnitude of understory production differences related to variation in soil properties.

\section{Study Area and Methods}

\section{Site Selection}

The study was conducted in the metamorphic zone (frigid soil temperature regime) and limestone plateau (Cryic and frigid soil temperature regime) physiographic areas of Pennington and Custer Counties (Fig. 1) (Feldman and Heimlich 1980). Soil classifica-

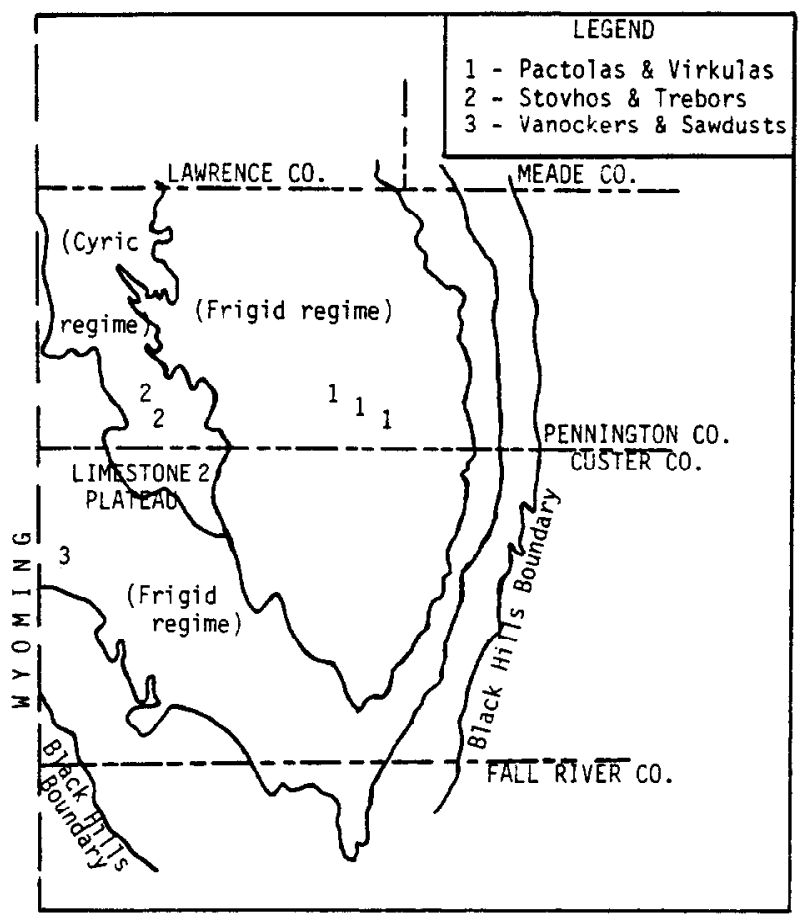

Fig. 1. The Black Hills area, including general site locations and soil temperature regimes.

tion, parent material and landscape position and aspect are described in Table 1. Cryic soil temperature occurs at elevations above $1,968 \mathrm{~m}$ (Meland 1979). Two major forest soils were selected within each region.

In the metamorphic zone, Pactola and Virkula series were selected. Pactola soils were further subdivided into north (N) and south (S) aspects since earlier observations indicated contrasting understory composition. Nearly level to undulating topography typified the cryic soil temperature regime on the limestone plateau. Major soil series selected in this regime were Stovho and Trebor. Steep, dissected topography occurred in the frigid regime of the limestone plateau. Swale positions were generally nonforested. Sawdust soils were developed on south aspects where a drier microclimate existed, while Vanocker soils occurred on the more moist north aspects. 
Table 1. Description of major solls within each geomorphic region inveatizated.

\begin{tabular}{|c|c|c|c|c|}
\hline Soil & Aspect & Classification & Parent Material & Hillslope Position \\
\hline Pactola & north & $\begin{array}{l}\text { loamy-skeletal, mixed } \\
\text { Typic Eutroboralfs }\end{array}$ & metamorphic schist and slate & backslopes and shoulders \\
\hline Pactola & south & $\begin{array}{l}\text { loamy-skeletal, mixed } \\
\text { Typic Eutroboralfs }\end{array}$ & metamorphic schist and slate & backslopes and shoulders \\
\hline Virkula & & $\begin{array}{l}\text { fine, montmorillonite, } \\
\text { Typic Eutroboralfs }\end{array}$ & metamorphic schist and slate & footslopes and toeslopes \\
\hline Stovho & & $\begin{array}{l}\text { fine, montmorillonite, } \\
\text { Typic Cryoboralfs }\end{array}$ & limestone & footslopes and toeslope \\
\hline Trebor & & $\begin{array}{l}\text { loamy-skeletal, mixed } \\
\text { Typic Cryoboralfs }\end{array}$ & limestone & backslopes and shoulders \\
\hline Vanocker' & north & $\begin{array}{l}\text { loamy-skeletal, mixed } \\
\text { Typic Eutroboralfs }\end{array}$ & limestone & backslopes and shoulders \\
\hline Sawdust ${ }^{2}$ & south & $\begin{array}{l}\text { loamy-skeletal, mixed } \\
\text { (calcareous), frigid, Typic } \\
\text { Ustorthents }\end{array}$ & limestone & backslopes and shoulders \\
\hline
\end{tabular}

'Tentatively reclassified from Loamy-skeletal, mixed, Typic Eutrochrepts

2Proposed series

Twelve sites were selected within each of the 7 soils so that the full range of canopy cover observed for the soil was represented. All sites had representative understory vegetation and had soils that fell within the range of characteristics for that particular soil series. Large homogeneous areas on slopes utilized by cattle $(<40 \%)$ (Byrd 1980) that had a minimum of 3 years for understory vegetation response following thinning (McConnell and Smith 1965) were selected.

Sites were distributed across the study area (Fig. 1). A transect at each site was established, generally running diagonal or perpendicular to the slope.

\section{Site and Understory Measurements}

Canopy cover was measured with a spherical densiometer (Lemon 1956) and basal area with a cruising prism (Dilworth and Bell 1972). Percent slope and aspect were also measured. Elevation was determined from U.S. Geological Survey quadrangle sheets.

Oven-dry understory production was determined by a doublesampling method (Pechanec and Pickford 1937, Wilm et al. 1944). Ten evenly spaced $20 \times 61-\mathrm{cm}$ quadrats were placed along each transect. Annual understory production was estimated by vegetation class (graminoids, forbs, and shrubs) within each quadrat during late July through early August in 1982 and 1983. These estimates were adjusted to $\mathrm{kg} / \mathrm{ha}$ by the use of a regression equation developed from clipping data derived from $20 \%$ of the quadrats.

\section{Data Analyses}

Mean yield by vegetation component was determined for each site. Stepwise multiple regression was performed to develop yield production models (Ray 1982).

Independent variables tested for predicted yield were the following: canopy cover, basal area, soil series, and seasonal (May-June) precipitation. Soils were treated as dummy variables. Interactions among important independent variables were also tested.

\section{Forage Potential}

Herbage yield (graminoids + forbs) and graminoid yield models were determined for each soil, using canopy cover as the independent variable. Independent palatability ratings of species were developed by USDA-SCS and USDA-USFS range specialists with experience in the Black Hills. Unpalatable components of yield determined by species inventories and compositional estimates were removed from the herbage production model to develop a potential forage production model for cattle.

\section{Results and Discussion}

\section{Important Independent Variables}

Canopy cover was the most important independent variable in the prediction of all yield components (Table 2). The negative coefficient associated with canopy cover in each equation reveals

Table 2. Yield' precipitation models using STEPWISE/MAXR. canopy cover soils ${ }^{2}$, precipitation ${ }^{3}$, and soil $X$ cover interactions $s^{4}$ represent independent variables. Best model tested for improvements SS (P.10.).

$$
\begin{aligned}
& \text { Graminoids } \\
& \text { Best Model } \quad \mathrm{Y}=2.8+12.1(\mathrm{VR})-.17(\mathrm{VRC})+18.5(\mathrm{ST})- \\
& .32 \text { (STC) }+8.9 \text { (PS) - .20 (PCS) }-.05 \text { (VAC) } \\
& -.06 \text { (SAC) }-.10 \text { (cover) }+.72 \text { (precip.) } \\
& \text { N, TR, VA, SA }=\text { intercept } \quad R^{2}=.68 \\
& \text { Best Model } \quad Y=3.7+8.1(\mathrm{VR})-.14(\mathrm{VRC})+1.3(\mathrm{ST})+ \\
& 1.0 \text { (VA) }-3.3(\mathrm{SA})+.06(\mathrm{SAC})-.08 \text { (cover) } \\
& +.21 \text { (precip.) } \\
& -.34 \text { (STC) }-9.0 \text { (PS) - .21 (PSC) }-2.9 \text { (SA) } \\
& -.19 \text { (cover) }+.92 \text { (precip.) }
\end{aligned}
$$

its inverse relationship to yield. Graminoids were more sensitive than forbs or shrubs to changes in canopy cover. Basal area was not as effective as canopy cover in predicting understory herbage yield production even though cover and basal area were highly correlated $\left(r^{2}=.91\right)$. These 2 variables were statistically evaluated jointly and independently. A regression equation was developed that 


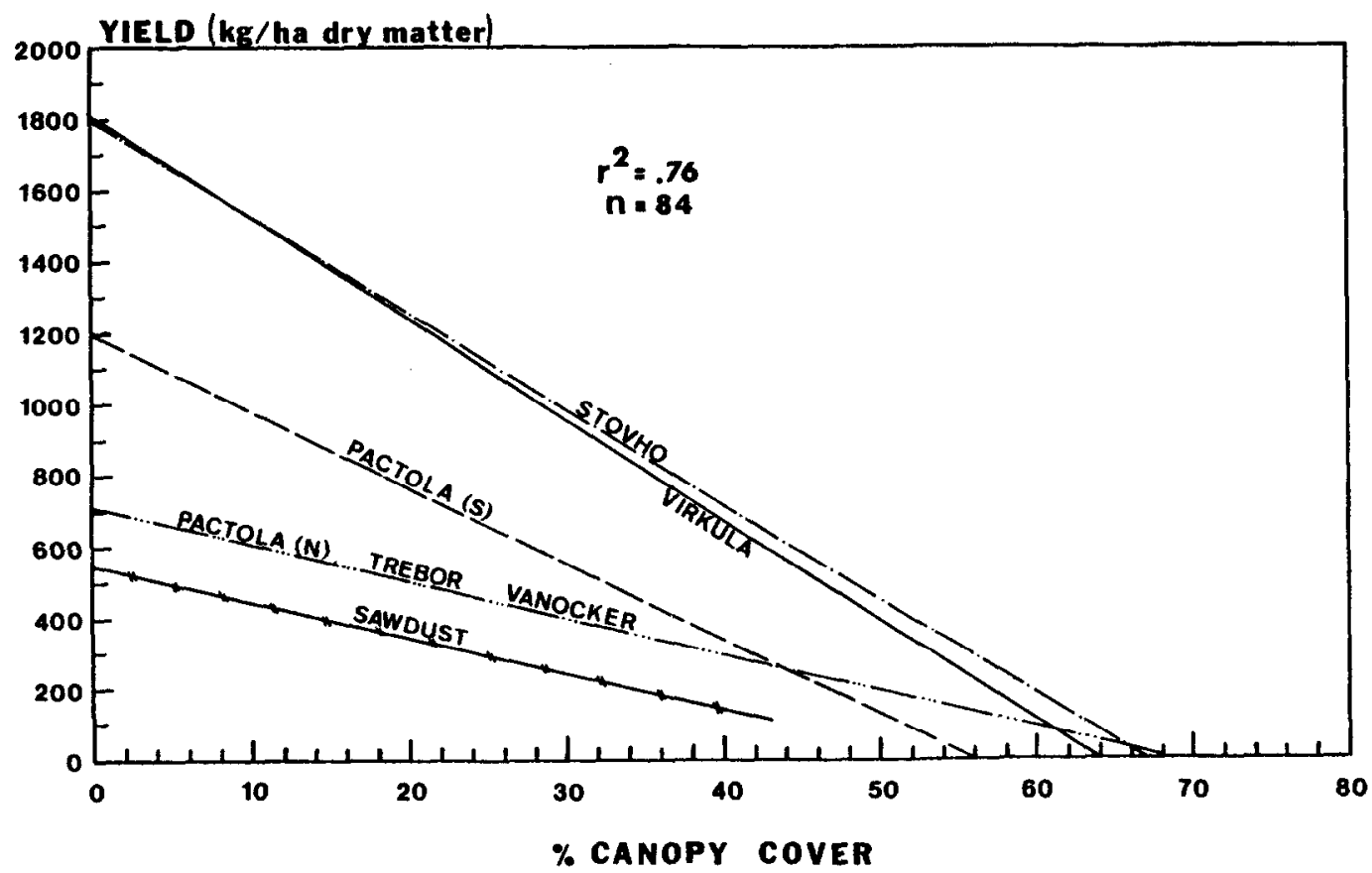

Fig. 2. Herbage production by soil using normal May-June precipitation.

allows conversion of basal area data to overstory canopy cover information for areas having only basal area data available.

The addition of certain soil series improved the sum of squares (SS) $(P<0.10)$ over canopy cover alone in all models. Those soil series that reacted significantly different $(P<0.10)$ from the other soils were identified as being different from the intercept by the introduction of the dummy variable into the regression equation.

Interactions between the 2 most important independent variables (canopy cover and soils) improved SS $(P<0.10)$ in all models. These interactions indicated that all soils were not responding similarly to changes in canopy cover. Higher yielding soils gener- ally contained a more negative interaction with cover (Table 2), resulting in a faster yield reduction as canopy cover increased with lower yielding soils (Fig. 2). At dense canopy covers, yields were similar among soils. This demonstrates the de-emphasis of soil properties influencing yield as canopy cover increases. With an open canopy, differences in soil production potentials can be fully expressed. A curvilinear relationship did not improve the predictive value of the developed model.

The precipitation variable also improved the predictive ability of all models (Table 2). Long-term yield predictions of native range have been developed using seasonal precipitation records (Rogler

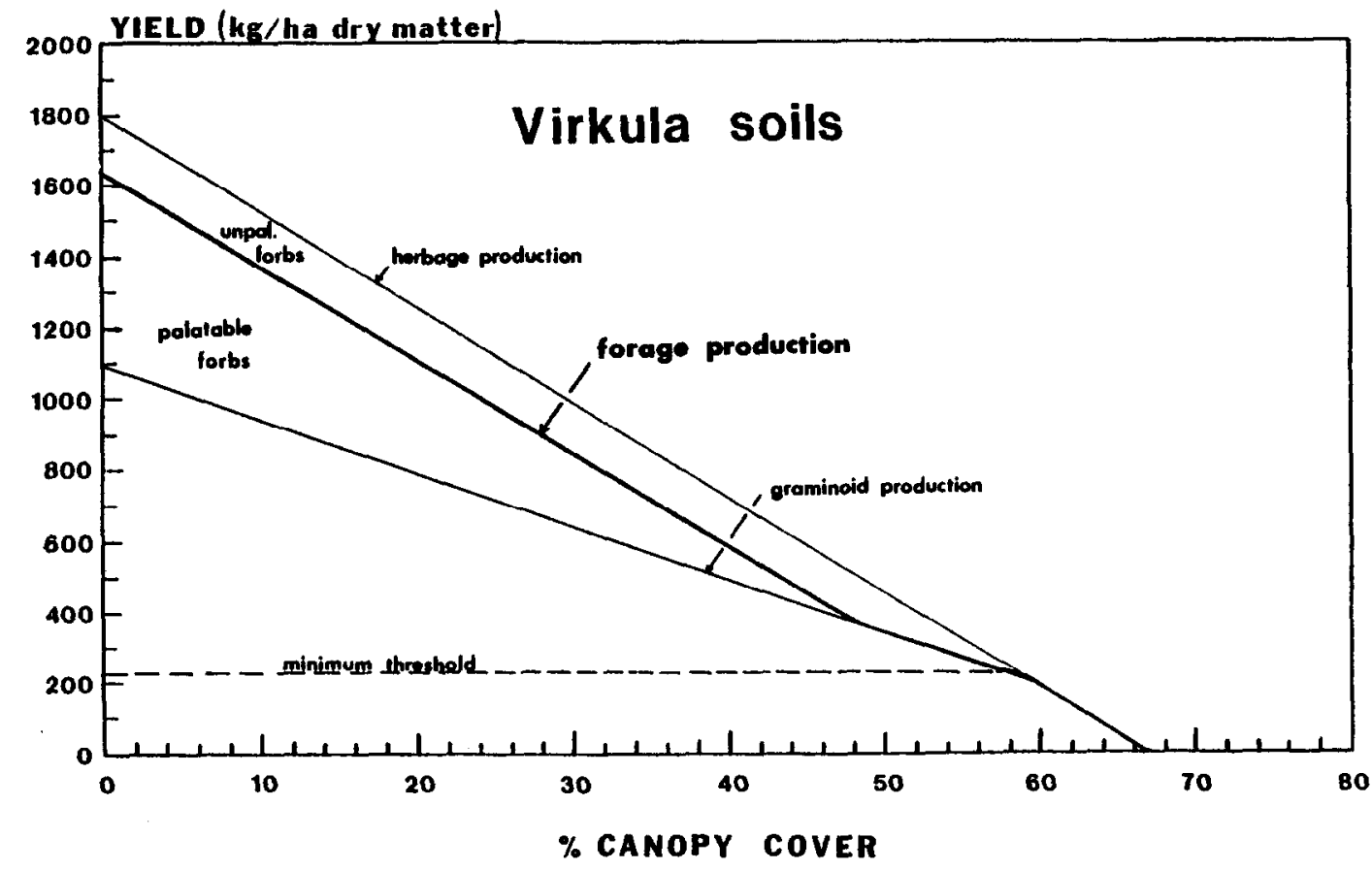

Fig. 3. Forage potential for normal May-June precipitation on Virkula soils. 
and Haas 1947, Smoliak 1956). In a mixed cool-/warm-season plant community, Smoliak found that May-June explained $74 \%$ of the variability in yield. Vegetation identified in this study was predominantly cool season. May-June precipitation averaged 24.9 $\mathrm{cm}$ and $13.5 \mathrm{~cm}$ in 1982 and 1983 respectively. The precipitation corresponds to high (1982) and low (1983) production years. It would be inappropriate to develop a long-term yield prediction model based on 2 years of data. However, normal May-June precipitation $(19.1 \mathrm{~cm})$ can be used in the model since it falls between the 2 years. Since the precipitation term was common to all soils for each yield component, changes in the coefficient caused parallel shifts when yield was regressed on canopy cover (Fig. 2). Thus, the inclusion of a precipitation term allows the development of a model that has long- and short-term applications. Forbs were least sensitive, while graminoids were most sensitive to changes in precipitation.

\section{Herbage Production Relationships}

Herbage production relationships among soils (Fig. 2) were developed from the model on Table 2. When yield was regressed on canopy cover, by soil, Stovho and Virkula soils had the highest production potential with a predicted yield of $1,800 \mathrm{~kg} / \mathrm{ha}$ at $0 \%$ cover with normal May-June rainfall.

Swale soils such as Stovho and Virkula (both nonskeletal soils) would receive more moisture than the skeletal soils in the study by virtue of landscape position. Sawdust soils were the lowest producers of herbage, with predicted yields of $550 \mathrm{~kg} / \mathrm{ha}$ under similar conditions. The regression line for Sawdust soils extended to only 43\% cover because greater canopy cover values were not observed on any sites. Stovho and Virkula soils occur in landscape positions that correspond to Clary and other's (1966) most productive soil topographic areas. Sawdust soils, positioned on southerly exposures, were least developed. Coarse fragment content of this soil was high. Sawdust profiles exhibited minimal development as the result of a high calcium carbonate content and droughty microclimate. Ground cover was more sparse on Sawdust soils than on other soils. Calcareous materials at or near the soil surface and surficial erosion were evident at all 12 Sawdust sites. These factors probably combine to make Sawdust soils low in productivity.

Although important morphological differences were not observed between Pactola soils on north and south aspects, understory production and composition were different. South aspects were dominated by graminoids, while north aspects were dominated by shrubs. Pactola (N) soils out-yielded Pactola (S) soils in total production primarily due to the dominance of shrubs. Considering only the herbage component, south aspects out-produced north aspects (Fig. 2). The major cause for vegetational contrast between aspects is probably microclimate differences.

\section{Forage Potential}

Graminoid and herbage models from Table 1 were incorporated into forage potential models by subtraction of nonpalatable yield components (Fig. 3).

Forage potential relationships among soils were comparable to those observed in the herbage production models. Although graminoid production on Virkula soils was over $300 \mathrm{~kg} / \mathrm{ha}$ less than on Stovho soils, high forb yields on Virkula soils resulted in comparable forage potential for these 2 soils. Soils with a southern aspect, Pactola (S) and Sawdust, had very few forbs to contribute to the forage potential. A low percentage of palatable forbs on Vanocker soils with moderate to dense canopy covers helped cause the forage component to diminish rapidly compared to other soils. Footslope (swale) soils had the greatest forage potential. Average forage potential in the frigid sedimentary region with an open canopy cover was less than other regions investigated because it had slightly less precipitation, warmer temperatures, and shallower soils. Soils at high elevations within the limestone plateau were comparable in forage potential to soils within the metamor- phic zone.

Forage potential varies as precipitation varies. Since graminoids are more sensitive to changes in precipitation than forbs, the graminoid component of forage will increase faster than the forb component as May-June precipitation increases. Grazable woodland sites may require periodic evaluation to determine if major changes in plant composition and resultant forage value have occurred as a result of changes in livestock management.

Soil series represent several important variables which are combining to influence understory vegetation. Landscape position heavily influences the effectiveness of rainfall. Colluvial/alluvial sediments in swales contained fewer coarse fragments and/or finer textures compared to soils developed on upland sites in the study area. Relatively low evapotranspiration and high rainfall occurs at higher elevations. This elevational difference is reflected in soil temperature regimes. Extreme microclimatic contrasts resulting from aspect are reflected in degree of forestation and soil profile development. Soils on southern exposures in the frigid sedimentary region were drier, supported less timber, and had less developed profiles than those on north aspects. Soil series were an effective means of quantifying forage potential for woodland grazing. Even though this paper has emphasized the importance of considering soils in grazable woodland management, many other parameters need to be incorporated in the final management plan for any natural resource.

\section{Literature Cited}

Byrd, M.A., compil. 1980. Forestland grazing. USDA Forest Service. Forestry Rep. SA-FR 10.

Clary, W.P., and P.F. Ffolliott. 1966. Differences in herbage-timber relationships between thinned and unthinned ponderosa pine stands. USDA Forest Serv. Res. Note. RM-74.

Clary, W.P., P.F. Ffolliott, and A.D. Zanter. 1966. Grouping sites by soil management areas and topography. USDA Forest Serv. Res. Note. RM-60.

Dliworth, J.R., and J.F. Bell. 1972. Variable probability samplingvariable plot and three-P. A Pocket Book. O.S.U. Book Stores, Inc. Corvallis, Ore.

Ehrenreich, J.H., and J.S. Crosby. 1960. Herbage production as related to hardwood crown cover. J. Forest. 59:564-565.

Feldman, R.M., and R.A. Heimlich. 1980. The Black Hills. Kendall/Hunt Pub., Dubuque, Ia.

Ffolliott, P.F., and W.P. Clary. 1975. Differences in herbage-timber relationships on sedimentary and igneous soils in Arizona ponderosa pine stands.

Gains, E.F., R.S. Campbell, and J.J. Brasington. 1954. Forage production on longleaf pine stands of southern Alabama. Ecol. 35:59-62.

Halls, L.K., and J.L. Schuster. 1965. Tree-herbage relations in pinehardwood forest of Texas. J. Forest. 63:282-283.

Lemmon, P.E. 1956. A spherical densiometer for estimating forest overstory density. Forest Sci. 2:314-320.

McConnell, R.R., and J.G. Smith. 1965. Understory response 3 years after thinning pine. J. Range Manage. 18:129-132.

Meland, A.C. 1979. Soil survey of Lawrence County, South Dakota. USDA Soil Conserv. Serv. and Forest Serv. U.S. Gov. Print. Off. Washington, DC.

Pase, C.P. 1958. Herbage production and composition under immature ponderosa pine stands in the Black Hills. J. Range Manage. 11:238-243.

Pechanec, J.F., and G.D. Pickford. 1937. A weight estimate method for the determination of range or pasture production. J. Amer. Soc. Agron. 29:894-904.

Pyke, D.A., and B.A. Zamora. 1982. Relationships between overstory structure and understory production in the grand fir/myrtle boxwood habitat type of north-central Idaho. J. Range Manage. 35:769-773.

Ray, A.A. ed. 1982. SAS users guide: statistics 1982 edition. SAS Institute Inc. Cary, N.C.

Rogler, G.A., and H.J. Hans. 1947. Range production as related to soil moisture and precipitation on the Northern Great Plains. J. Amer. Soc. Agron. 39:378-389.

Smoliak, S. 1956. Influence of climatic conditions on forage production of shortgrass rangeland. J. Range Manage. 9:89-91.

U.S. Forest Service. 1983. Final environmental impact statements, Black Hills National Forest. U.S. Gov. Print. Off. Washington, DC. 
Wilm, H.G., D.F. Costello, and G.E. Klipple. 1944. Estimating forage yield by the double sampling method. J. Amer. Soc. Agron. 36:194-203.

Wolters, G.L. 1973. Southern pine overstories influence herbage quality. J. Range Manage. 26:423-426.
Wolters, G.L. 1982. Longleaf and slashpine decreases herbage production and alters herbage composition. J. Range Manage. 35:761-763.

Woods, R.F., D.R. Betters, and E.W. Mogren. 1982. Understory herbage production as a function of Rocky Mountain aspen stand density. J. Range Manage. 35:380-381. 